\title{
Transformation of a Sedan car (volkswagen) to hybrid and fully electric
}

\section{Transformación de un auto Sedan (volkswagen) a híbrido y totalmente eléctrico}

\author{
CHAVEZ-MENDOZA, Juan Manuel*† \\ Universidad Tecnológica Fidel Velázquez \\ ID $1^{\text {st }}$ Author: Juan Manuel, Chavez Mendoza
}

\begin{abstract}
In this work, a proposal is made to transform the vw sedan vehicle into a hybrid and electric vehicle as a viable alternative, to reduce polluting emissions from combustion vehicles and the high costs that conventional fuels have managed to achieve in recent times, New structures have been implemented to improve vehicle propulsion conditions by reducing pollutants. For this reason, the option of vehicles that contain two systems to generate their operation is attractive. The option that we are going to analyze is a hybrid vehicle with a parallel arrangement, in which the electrical energy that drives it comes from batteries and alternatively from an internal combustion engine that drives a generator. Typically, an internal combustion engine can also drive the wheels directly. In the design of a hybrid car, the heat engine is the energy source that is used as last option, and an electronic system is arranged to determine which engine to use and when to use it.
\end{abstract}

Conversion, Electrical Energy, Pollution

\section{Resumen}

El este trabajo se hace una propuesta de transformación del vehículo vw sedán a hibrido y eléctrico como una alternativa viable, para reducir las emisiones contaminantes por parte de los vehículos de combustión y a los elevados costos que los combustibles convencionales han logrado alcanzar en los últimos tiempo, se han comenzado a implementar nuevas estructuras que permitan mejorar las condiciones de propulsión del vehículo reduciendo los contaminantes. Por este motivo es que resulta atractiva la opción de vehículos que contienen dos sistemas para generar su funcionamiento la opción que vamos a analizar es de vehículo híbrido con un arreglo en paralelo, en el cual la energía eléctrica que lo impulsa proviene de baterías y alternativamente de un motor de combustión interna que mueve un generador. Normalmente, un motor de combustión interna también puede impulsar las ruedas en forma directa. En el diseño de un automóvil híbrido, el motor térmico es la fuente de energía que se utiliza como última opción, y se dispone un sistema electrónico para determinar qué motor usar y cuándo hacerlo

Conversión, Energía $\quad$ Eléctrica,
Contaminación

Citation: CHAVEZ-MENDOZA, Juan Manuel. Transformation of a Sedan car (volkswagen) to hybrid and fully electric. Journal of Mechanical Engineering. 2020. 4-14: 18-23

\footnotetext{
* Correspondence to the Author (e-mail: jmanuel.chavez@utfv.edu.mx)

$\dagger$ Researcher contributing as first author.
} 


\section{Introduction}

The implementtation of this work is to establish a solution to the need to create new vehicles that have less polluting emissions. In our case, we chose the Volkswagen "vocho" sedan vehicle, where calculations and research were carried out for the conversion of electric and hybrid vehicles, knowing that the start of this vehicle is in Germany. In 1933, Ferdinand Porsche met with Adolf Hitler to discuss the idea of the Volkswagen. Hitler wanted a vehicle that was capable of transporting 5 people at $100 \mathrm{~km} / \mathrm{h}$ and cost only 1000 Marks at that time.

This was Ferdinand Porsche's opportunity to carry out his idea and at the same time help Hitler to deliver him to the Volkswagens. Our task as an engineer is in the evolution of the car, where it has been introduced to electric and hybrid vehicles, this idea was started in 1938 when Robert Davidson managed to move a locomotive at $6 \mathrm{~km} / \mathrm{h}$ without using coal or steam. The electric car triumphs for its simplicity, reliability, smooth running, energy costs,

Starting this work, the main characteristics of electric and hybrid cars were analyzed, it was found that the classification depends on the type of current it handles (direct / alternating), in the position of the motor (series, combined, parallel) the batteries are also a data very important since it is the heart of the system and the most expensive and heavy element. The battery not only stores electrical energy for use in the vehicle, but also determines the power that the engine can use, the range and the design of the vehicle. We found a compatible motor (impulse $9 \mathrm{ev} \mathrm{dc}$ ). It is a 9.25 diameter DC motor with a double-ended shaft and is pre-drilled to allow the brush to advance. After showing all the technical data, the entire calculation memory will be delivered, thus having a theoretical argument for future generations.

\section{History VOLKSWAGEN SEDAN}

Literally the meaning of the word "Volkswagen" is "the people's car". In Germany, the idea was not exactly new. Before the 1930s, many efforts were made to create simpler cars that were available to everyone, but none did it like the Volkswagen.
Almost all automobiles before the 1930s, even when they tried to satisfy the simplest needs of workers, far exceeded their capacity to borrow. After the Second World War, a phenomenon began to be seen in which car owners modified them, this arose in some cases due to the need to have elements that would distinguish them from those that were produced in series.

At the beginning, small changes were made that over time became structural modifications that surprised locals and strangers. The car went from being a means of transport to a luxury that projects the personality of drivers who are increasingly concerned about the accessories of their vehicle. The demand for the phenomenon was so great that companies dedicated to providing accessories of all kinds to modify vehicles were established, they are called boutique cars, they are in charge of modifying the components of the cars and even their structure. The people who are dedicated to this business know mechanics, electronics and motor engineering to ensure that the results are the most convincing (VOLKSWAGEN, n.d.)

\section{The electric vehicle}

Steam could not replace the horse carriage, a new competitor came out. After the first experiments by Jedlik (1828, pictured) and Thomas Davenport (1835), we found the first electric vehicle in 1838, when Robert Davidson managed to move a locomotive at $6 \mathrm{~km} \mathrm{/} \mathrm{h}$ without using coal or steam. Between 1832 and 1839 Robert Anderson invented the first electric traction carriage, with a non-rechargeable battery. Shortly after the electrified line was patented, but that was not valid for cars, only for trolleybuses or trains. The first rechargeable batteries appeared before 1880, that's where they really began.

They took over the roads in a short time, in 1900 we can consider their apogee, when they were the cars that were sold the most, much more than those of steam or gasoline. In fact, in 1899 an electric car, "La Jamais Contente", exceeded $100 \mathrm{~km} / \mathrm{h}$ for the first time and set a speed record. The first gasoline cars were very polluting, dirty, noisy, required gasoline or gasoline (it was not easy to buy it at first), you had to change gear very rudimentary, you had to start them with a crank and anywhere they were susceptible to failure. 
That ended up changing... a bit. The electric car triumphed due to its simplicity, reliability, smooth running, no gear change or crank, they made no noise, they were fast, their autonomy was reasonable and their cost was bearable for the bourgeoisie and the upper classes, the first users of automobiles. They outperformed gasoline by 10 to 1 . However the gasoline car received the starter motor (1912), Henry Ford invented mechanized mass production, gasoline reached a very popular price, roads began to be opened to traffic and then autonomy became a highly valued feature, in addition to the price. (COSTAS, MOTORPASION, 2010)

\section{The electric vehicle}

Today the electric vehicle represents $3 \%$ of the total world vehicle fleet and according to Navigant Research, that percentage will increase to $7 \%$ by 2020 (around 6.6 million cars per year). You can think of the electric car as a recent innovation making its way onto the market. However, being strict the electric car is not exactly a novelty. In fact, the first models hit the streets during the first half of the 19th century and were so popular that by 1900 they already represented a third of the cars of the time. The combustion car replaced it for its lower cost and ended up almost in oblivion.

Today is back and to stay. Its characteristics and qualities fit very well to our present day where the economy and the environment demand alternatives. The key is in its engineering, but how does it work? Everything is based on electric motors that convert electricity into mechanical energy to move the wheels. Its operation is relatively simple, at least compared to combustion. But we explain it a little more in detail. The most characteristic elements of electric vehicles are the charging port, transformer, battery, controller and the motor. (AGUILAR, 2015)

\section{Loading port}

The charging port of an electric car is the point through which we recharge the car. Generally, it is an exterior outlet in the style of the gas outlet of conventional cars. Each brand manufactures its own type of ports but they are usually threephase contacts. To make it clearer, this is where you plug the car into electricity. As it is, it is the power input port to our unit.

\section{Transformer}

They are responsible for transforming the intensity and voltage of the electric current into valid values for the operation of the car. They also help cooling avoiding spills and accidents.

\section{Controller}

The controllers ensure that the operation is optimal, since it receives and recharges the energy of the motor. By needing few elements to function, the electric car becomes much more efficient than a combustion car, since they can convert up to $60 \%$ of their energy into mechanical energy; an internal combustion car that only converts up to $20 \%$.

Options are: DC brushed motor, induction motors, and more. Within each of these options there are others, for example, in motors with DC brushes, it can have a wound field or with permanent magnets. This is also true for a brushless motor, although when looking for cheaper options, DC motors are the lowest priced. Currently we only recommend systems with brushes in the case of personal use projects where you have a small budget and efficiency is not the most important factor. (AGUILAR, 2015)

\section{Current type}

Now when it comes to commercial projects or where features such as high efficiency, zero maintenance, and operational reliability are needed, AC motors are definitely the right fit. Currently a good AC motor and its Speed Controller (Invert) with regenerative braking capability only cost a few dollars more than older DC systems. (Barrios, 2014)

\section{DC (Direct Current)}

In cars that have a direct current electric motor, this battery would be directly connected to the motor. On the other hand, in electric cars that have an alternating current electric motor, the battery is connected to an inverter. Lithium-ion batteries store the energy given by the charger in the form of direct current (DC). This main battery is the means by which the entire electric car is powered. This type of engine is more traditional, the acceleration is slower, but it has a very high maximum speed. Furthermore, direct current motors are less expensive than alternating current motors.

CHAVEZ-MENDOZA, Juan Manuel. Transformation of a Sedan car (volkswagen) to hybrid and fully electric. Journal of Mechanical Engineering. 2020 


\section{AC (Alternating Current)}

In electric cars that have an alternating current electric motor, the battery is connected to an inverter. AC electric motors have a good reputation as they are used in cars from TESLA and Nissan, among other companies. They are more expensive than DC motors, but have a fast acceleration rate and are compatible with regenerative braking systems. This system converts the momentum of the electric motor and uses it to recharge the batteries. (Electricocar, 2013)

\section{Hybrid Vehicle Features}

A hybrid combines two engines, an internal combustion engine and an electric one powered by additional batteries to the main one. They have been a reality for many years and little by little they begin to become popular due to the crisis, fuel hikes, cheaper technology and environmental awareness.

\section{Classification}

- $\quad$ Series hybrid: The internal combustion engine (hereinafter heat engine) has no mechanical connection with the wheels, it is only used to generate electricity. This engine runs at optimum speed and recharges the battery until it is full, at which point it is temporarily disconnected. Traction is always electric. Parallel hybrid: Both the heat engine and the electric engine are used to power the transmission at the same time. It is a relatively simple solution, but it is not the most efficient.

- Combined hybrid: Any combination of the two engines serves to drive the car, it is like a series hybrid but with mechanical connection to the wheels. It is a very efficient solution but much more complex at a mechanical and electronic level. (COSTAS, MOTORPASION, 2009)

The most efficient system is in series, and the less the parallel. There is another way to classify hybrids:
- $\quad$ Micro hybrid: At stops the heat engine is switched off. When you want to resume running, a reversible alternator starts the engine using energy recovered before stopping. It only saves on urban cycle and there is no electric motor to power the car.

- $\quad$ Semi-hybrid or mild-hybrid: The electric motor is used as an assistance to the heat engine and is also a generator of energy during braking and holding, but it cannot be powered $100 \%$ electrically (heat engine off), although it can with the heat engine without consume but moving its mechanical parts.

- Pure hybrid or full-hybrid: It can be circulated under certain conditions only with the electric motor, while the thermal is completely off and does not move its parts. This change can be automatic or voluntary.

- $\quad$ Plug-in hybrid or PHEV: It belongs to this group if its batteries are rechargeable using conventional electrical energy, that is, by plugging it in, and it travels at least 20 miles without the need for another propulsion system.

- $\quad$ Extended range electric car or EREV: As in the previous case, but it is also a series hybrid. In practice, they are considered electric cars because they do not need the heat engine other than to sustain the load, and they can operate $100 \%$ without them. This means that when the batteries run out, the heat engine is used only to generate electricity at a constant rate to increase autonomy at a very low cost per kilometer.

MOTORPASION, 2009)

(COSTAS,

\section{Calculation memory}

Power needed to overcome drag:

$P w=(R t * v) /(75 * n t)$

$P w=(215.0576 * 35.2777) /(75 * 0.85)$

$\mathrm{Pw}=119.0076 \mathrm{CV}$

$\mathrm{Rt}$ : resistance to advance $(\mathrm{kg})$

$\mathrm{v}$ : car speed $(\mathrm{m} / \mathrm{s})$

$\mathrm{nt}$ : transmission performance

Calculation of the gearbox ratio and its speeds

$R d=\frac{205 *(80.60 * 2)+25.4 * 15}{2}=313.5 \mathrm{~mm}$

$R f=\frac{n m \times 2 \pi x R d}{r 4 x v \max x 60}=\frac{4400 * 2 \pi * 0.3135}{88 * 35.2777 * 60}=4.653$ 
$\mathrm{Rd}$ : wheel radius in $\mathrm{m}$ $\mathrm{nm}$ : engine rpm rf: differential ratio vmax: maximum speed of the car in $\mathrm{m} / \mathrm{s}$ $\mathrm{n} 2$ : rpm at maximum power $\mathrm{n} 1$ : rpm at maximum torque $\mathrm{r} 1, \mathrm{r} 2, \mathrm{r} 3$ and r4: gear ratio of each gear

$$
\begin{aligned}
& r 4=\frac{n 2 \times 2 \pi x R d}{r f \times v \max 60}=\frac{4400 * 2 \pi * 0.3135}{4.653 * 35.2777 * 60}=0.880 \\
& r 3=r 4 x \frac{n 2}{n 1}=0.88 \frac{4400}{2600}=1.4892 \\
& r 2=r 3 x \frac{n 2}{n 1}=1.4892 \frac{4400}{2600}=2.52 \\
& r 1=r 2 x \frac{n 2}{n 1}=2.52 \frac{4400}{2600}=4.2 \\
& r m a=\frac{n 2 \times 2 \pi x R d}{r f \times \text { vmaxx } 60}=\frac{4400 * 2 \pi * 0.3135}{4.653 * 8.001 * 60}=3.88
\end{aligned}
$$

\section{Driving effort}

$F=\frac{M m \times \text { rixrfxnt }}{R d}=\frac{103.986 * 2.6923 * 4.653 * 0.85}{0.3135}=$ 3531.9351 N

$\mathrm{Mm}$ : Torque at the motor

$\mathrm{F}$ : Motive effort

$\mathrm{Mm}=10.6 \mathrm{~kg}-\mathrm{m}=103.986 \mathrm{~N}-\mathrm{m}$

Acceleration capacity

$\gamma=\frac{F-R t}{m e}=\frac{3531.9351-2109.715}{1212}=1.173$

$\mathrm{Me}=1.01 \times \mathrm{x}=1.01 * 1200=1212 \mathrm{~kg}$

Acceleration time 0 to $100 \mathrm{~km} / \mathrm{hr}(27.77 \mathrm{~m} /$ sec)

$$
\begin{aligned}
& t v f-v i=1 / \gamma \int_{v i}^{v f} d v \\
& t 0-27.77=1 / 1.1734 \int_{0}^{27.77} d v= \\
& 23.6728 \text { seg }
\end{aligned}
$$

\section{Vehicle power and torque calculation}

The engine has a Troque of $10.6 \mathrm{~kg}-\mathrm{m}$ at 2600 rpm and a maximum power of 55 hp @ 4400 rpm.

To convert from horsepower to horsepower, multiply by 0.985923 which is the Conversion Factor.

That is, $55 \mathrm{hp} \times 0.985923$ Fac. $=55.785 \mathrm{Cv}$

\section{Modifications to be made for the $100 \%$ electrical conversion}

Electric motor and batteries. For the electric motor there is the IMPULSE 9 EV DC model. It is a 9.25 "diameter, direct current with a doubleended shaft and is pre-drilled to allow the advancement of the brush, either in neutral, CWDE advanced or advanced CCWDE (standard). With the motor specifications we know that a voltage of $144 \mathrm{v}$ to $450 \mathrm{~A}$ is necessary each individual battery handles $24 \mathrm{v}$ to 18 then to compensate. Advantages of the Lithium-Ion battery over conventional lead-acid batteries

- $\quad$ High energy density: more energy with less weight;

- High charging currents (shortens charging time

- High discharge currents (allows, for example, to power an electric stove with a small battery bank);

- $\quad$ Long battery life (up to six times longer than a conventional battery)

- High efficiency between charging and discharging (very little energy loss due to heating);

- Greater continuity of the available current.

\section{- Battery Specifications:}

Lithium-Ion batteries 24V 180Ah 4.75kWh

Technology Lithium Iron Phosphate (LiFePo4)

Nominal voltage $26.4 \mathrm{~V}$

Nominal capacity $180 \mathrm{Ah}$

Nominal power $4.75 \mathrm{KWh}$

Weight $55 \mathrm{~kg}$

Power / weight ratio $86 \mathrm{Wh} / \mathrm{kg}$

Dimensions (hxwxd) $625 \times 195 \times 355 \mathrm{~mm}$

Load cut-off voltage at $0.05 \mathrm{C} 28.8 \mathrm{~V}$

Discharge cut-off voltage $20 \mathrm{~V}$

Charge / discharge current

recommended $54 \mathrm{~A}(0.3 \mathrm{C})$

Maximum charge current (1C) $180 \mathrm{~A}$

Maximum discharge current (1.5C) $270 \mathrm{~A}$

Pulse discharge current (10s) $1,000 \mathrm{~A}$

Number of cycles @ 80\% DOD (0.3C) 2000

Series configuration Yes, up to 2

(more series if requested)

Parallel configuration Yes, easily up to 4

(more in parallel if requested)

Temp. working load $0 \sim 45^{\circ} \mathrm{C}$

Temp. working for discharge $-20 \sim 55^{\circ} \mathrm{C}$

Temp. storage $-20 \sim 45{ }^{\circ} \mathrm{C}$

Table 1 Battery data sheet (Compan, 2016) 


\section{Results}

Given the characteristics of the chassis of the selected car, the electric motor was installed directly to the transmission through a coupling plate, and the battery pack was arranged on the floor of the rear seat of the car itself, the junction boxes and control accessories were installed. distributed in the front trunk of the car. The entire assembly and testing process was carried out at the facilities and the vehicle was safeguarded from the sponsors for final disposal.

\section{References}

AGUILAR, C. A. (3 de MAYO de 2015). MOTORBIT. Recuperado el 2016, de http://motorbit.com/asi-funciona-un-motor-deauto-electrico/?pais=

Barrios, G. G. (2014). AUTO LIBRE. Recuperado el 2016, de http://autolibre.blogspot.com/2009/05/cual-esel-mejor-motor-para-un-auto.html

Compan, E. C. (2016). ELECTRIC CAR PARTS

COMPANY. Obtenido de http://www.electriccarpartscompany.com/ImPul se-9-EV-DC-Motor-br-72-156V-400A-br-

Double-ended-shaft--advanced-timing-1125-

DE-Shaft-1125-CE-Shaft_p_68.html

COSTAS, J. (18 de MAYO de 2009). MOTORPASION. Obtenido de http://www.motorpasion.com/coches-hibridosalternativos/que-es-un-coche-hibrido

COSTAS, J. (7 de MAYO de 2010). MOTORPASION. Recuperado el 2016, de http://www.motorpasion.com/coches-hibridosalternativos/historia-de-los-coches-electricos

Electricocar. (4 de NOVIEMBRE de 2013). ELECTRICOCAR. Recuperado el 2016, de http://www.electricocar.com/motores-paracoches-electricos.html

Energy, V. (s.f.). victronenergy bluepower. Obtenido de https://www.victronenergy.com/upload/docume nts/Datasheet-Lithium-ion-and-Lynx-ionES.pdf
VOLKSWAGEN, H. D. (s.f.). Especificaciones por Año. Recuperado el 2016, de VW tiene el record:

http://oldvwgarage.com/vws/historia_del_voch o.htm\#Historia 